\title{
Sá, Lúcia. Life in the Megalopolis: Mexico City and São Paulo. London and New York: Routledge, 2007.
}

At the start of her latest book, Lúcia Sá explains the intellectual trajectory that led her to a study of the Latin American megacities of Mexico City and São Paulo by way of Mário de Andrade's Macunaíma: "in order to recover his muiraquitã, the eponymous Mário de Andrade traveled from one end of Brazil to the other, the Amazon to São Paulo, and in a sense, having completed Rain Forest Literatures (2004), this is what I have attempted to do in this study" (x). Such a work, following one on the literatures of the Amazon, underscores Sá's admirable commitment to exploring the literary and cultural extremes of her native Brazil, while at the same time incorporating other materials that make a more comparative discussion with internal indigenous cultural elements or other Latin American societies possible.

In setting up the thematic framework for this work, Sá remarks on how her first visit to Mexico City "provoked a certain sensation of déjà vu" (1); after all, these are Latin America's two largest cities and for that reason alone they merit this sort of comparative cultural analysis. From the outset, Sá is quick to point out that such an extended comparison will necessarily uncover as many divergences as it does similarities. In fact, it might be unfair to other urban spaces in the region to attribute to these two cities what might be called a form of megalopolitan exceptionalism, as there are of course other urban conglomerations that would easily qualify within any strict definition of a Latin American megalopolis. Buenos Aires, one of the world's largest cities with over 12 million inhabitants, is the most obvious example of what must be set aside in order to privilege the Mexico City-São Paulo axis in this study. Rio de Janeiro, given its traditional rivalry with São Paulo, is a bit more difficult to ignore, and Sá does well to recognize it as part of her introduction. In contrast to the Brazilian case of interurban rivalry, however, she states that "the main difference here is that Mexico City has no plausible rival in the national 


\section{Reviews}

scene" (16). Yes, perhaps not in a strictly national framework, but in the context of present transnational realities one might do well to mention that other Mexican(-American) megalopolis of Los Angeles-San Diego-Tijuana (something that perhaps could have been explored fruitfully in Sá's later discussion of González Iñarritu's 2006 film Babel). Moreover, as populations in other cities continue to grow and understandings of the often porous borders of Latin America and what qualifies as a megacity within this cultural context shift accordingly, so will the ways in which the single factor of sheer size predicates our understandings of cultural importance and centrality in and beyond the boundaries of "Latin America's two megalopolitan cities" (15; emphasis mine).

According to Sá, the materials that form the primary corpus of this work were collected in situ: "for the most part, books were acquired on location, at bookstores in Mexico City and São Paulo, most often in fact at Ghandi (sic) in Mexico and Livraria Cultura in São Paulo" (8). For this reason, it might seem contradictory to some to follow such an assertion with a discussion of urban flânerie accompanied by a quote from Walter Benjamin. The idea that any metropolitan academic's sources are acquired primarily "on the ground" is a difficult claim; those closely linked to an Anglo-American academic institutional network are never far from its common points of reference and personal contacts, a fact evinced in the book's often parallel strategic politics of quotation and acknowledgement. Such textual material is not merely supplementary, but an equally primary body of text that we, as North American and European-based academics, would do well to acknowledge explicitly as central to the development of our critical discourse.

With this in mind, the question of what it truly means to be an urban "outsider" today, whether in a presumably foreign city like Mexico City or one's own hometown of São Paulo, is perhaps the most provocative question raised by this study. Not only the aforementioned separation of academic background, but also those conditioned by constructions of "race," ethnicity and socioeconomic background, all func- 
tion to ensure that no space called "home" is completely familiar, nor, for that matter, the privileged spaces of other cities are ever completely foreign. Sá selects excellent illustrative examples that encourage this kind of discussion: Mexican intellectual Carlos Monsiváis's urban chronicles, Eduardo Emílio Fenianos's "radical adventure" through the unexplored areas of his native São Paulo, paulista hip-hop artists such as Racionais or the oral narratives of Mexican street vendor Chata Aguayo. While there is something to be said for anthropologist Néstor García Canclini's contention that citizenship is defined increasingly by patterns of consumption (101), Sá's examples of segregation in these two Latin American urban environments underscore the persistent role of "race" and ethnicity in the construction of citizenship and national identity.

Nowhere is this more apparent than in the final chapter, which ends with a discussion of how the rich of these two cities "hardly ever serve as subjects per se of cultural representations" (154). As a counterexample, Sá concludes with a series of photographs from Daniela Fossell's 2003 exhibition Ricas y famosas. The female subjects are photographed in their opulent homes in gated communities, which Sá accurately describes as "strange and highly exoticized" (154)but might the recurrent discussions of race (to say nothing of taste) that intervene in the analysis of other works in this study also be applied here? Is not the "whiteness" of these women as visible as the "blackness" of a hip-hop artist or the "indigenous" ethnic background of a street vendor? After all, if the rich are truly more capable of controlling their own image, as Sá asserts here, how might intellectual critique serve to dismantle that advantage? Her book takes an important step in pointing us in that direction.

Christopher Larkosh University of Massachusetts Dartmouth 